\title{
ANALISIS PERANCANGAN SISTEM ADMINISTRASI PELAYANAN PUBLIK KANTOR DESA CISAAT MENGGUNAKAN JAVA NETBEANS
}

\author{
Endang Triana \\ Program Studi Teknik Informatika, Fakultas Teknik dan Ilmu Komputer, \\ Universitas Indraprasta PGRI \\ Jalan Raya Tengah No 80, Kelurahan Gedong, Pasar Rebo, Jakarta Timur \\ e.triana89@yahoo.co.id
}

\begin{abstract}
Abstrak
Desa Cisaat di Kecamatan Cicurug Kabupaten Sukabumi berupaya melaksanakan pelayanan administrasi kepada masyarakat sesuai dengan prinsip pedoman standar pelayanan yang berlaku. Untuk peningkatan mutu pelayanan maka, dibutuhkan suatu sistem pelayanan sehingga mempermudah kinerja penyelenggara pelayanan di kantor desa dan meningkatkan kualitas pelayanan aparat yang menjadi sistem terkomputerisasi serta mempermudah pendataan dan pengarsipan data administrasi warga. Sistem yang dihasilkan dapat digunakan untuk melayani proses permohonan warga berupa surat pengantar permohonan pembuatan E-KTP, permohonan pembuatan kartu keluarga, surat keterangan lahir, surat keterangan kematian, surat pengantar permohonan SKCK, surat permohonan keterangan domisili dan surat keterangan usaha yang dibutuhkan warga untuk proses selanjutnya di tingkat kecamatan atau lembaga terkait.
\end{abstract}

Kata Kunci: Analisis, Sistem, Administrasi, Pelayanan, Publik.

\begin{abstract}
Cisaat Village in District Cicurug Sukabumi regency seeks to carry out administrative services to the community in accordance with the principles of guidelines applicable service standards. To improve the quality of service, a service system is needed so as to facilitate the performance of service providers in village offices and improve the quality of services apparatus that becomes a computerized system and facilitate the data collection and archiving of citizen administration data. The resulting system can be used to serve the application process of citizens in the form of a cover letter for the creation of E-KTP, application for making a family card, birth certificate, death certificate, letter of introduction to SKCK application, letter of application for domicile certificate and business certificate needed by citizens for further process at the sub-district or related institution level.
\end{abstract}

Keywords: Analysis, System, Administration, Service, Public.

\section{PENDAHULUAN}

Dengan berkembangnya suatu sistem informasi maka sebuah organisasi memerlukan suatu alat yang dapat mengolah data dengan cepat dan tepat agar menjadi suatu informasi. Karena tingkat ketersediaan data ini semakin banyak dan jelas sehingga dapat membantu dalam pengambilan keputusan dan kebijakan-kebijakan strategis dalam organisasi.

Setelah melakukan survey dan menerima hasil monitoring dari Kepala Desa Cisaat untuk kinerja administrasi pelayanan publik, ternyata sistem pelayanan dan pengarsipan data yang dilakukan di kantor desa tersebut masih bersifat manual (komputerisasi sederhana). Ketika ada warga yang ingin memperbaiki surat keterangan yang telah mereka buat, pegawai desa memerlukan waktu yang cukup lama untuk mencari data surat keterangan tersebut dan saat ingin membuat laporan pelayanan yang telah dilakukan harus merekap kembali data-data yang sudah dibuat. Hal ini mengakibatkan pelayanan yang dilakukan kantor desa tersebut kurang maksimal dan pengarsipannya kurang efektif. Dalam penyimpanan data pun pemerintahan desa tidak memiliki password khusus sehingga data bisa dibuka oleh semua orang dan bisa menimbulkan penyalahgunaan data. Dengan mengetahui keadaan tersebut peneliti mencoba untuk memperbaiki sistem pelayanan yang ada di Kantor Pemerintahan Desa menjadi pelayanan yang terkomputerisasi sesuai dengan perkembangan teknologi sekarang, yang nantinya dapat membantu dan mempermudah para perangkat desa dalam pelayanan, mengarsipkan data dan pencarian data secara cepat. 
Tujuan dari penelitian adalah untuk merancang sebuah sistem baru yang lebih terkomputerisasi sehingga memudahkan para perangkat desa untuk memberikan pelayanan kepada warga serta memudahkan perangkat desa dalam pengarsipan data, pencarian data dan pembuatan laporan.

\section{PENELITIAN RELEVAN}

Penelitian yang dilakukan oleh (Marzihan Amin, 2013) yang berjudul "Analisis Fungsi Administrasi Pemerintahan Desa Dalam Peningkatan Pelayanan Publik Di Desa Perincit Kecamatan Pusako Kabupaten Siak" Tujuan penelitian yang dilakukan adalah untuk mengetahui bagaimana fungsi administrasi dalam meningkatkan pelayanan publik di kantor Kepala Desa Perincit dan untuk mengetahui apa saja hambatan administrasi pemerintahan desa dalam peningkatan pelayanan publik di Desa Perincit Kecamatan Pusako Kabupaten Siak.

Penelitian yang dilakukan oleh (Muchamad Andre Wicakso, 2016) yang berjudul "Analisi Perancangan Sistem Pelayanan Terpadu Satu Pintu (Studi Kasus Kelurahan Kramat Jati) Menggunakan Java dan Mysql". Tujuan penelitian yang dilakukan adalah untuk merancang sistem baru yang lebih terkomputerisasi sehingga memudahkan pegawai kelurahan untuk memberikan pelayanan kepada warga masyarakat serta untuk memudahkan pegawai kelurahan dalam pengarsipan data, pencarian data dan pembuatan laporan.

Penelitian yang dilakukan oleh (B \& Angwarmasse, 2012) yang berjudul "Model Antrian FIFO (First-In First-Out) Pada Pelayanan Mahasiswa Fakultas Teknik Universitas Janabadra Berbasis Multimedia". Tujuan penelitian yang dilakukan adalah untuk memudahkan mahasiswa untuk mendapatkan pelayanan yang ada pada fakultas teknik Universitas Janabadra dan mengurangi waktu mahasiswa yang sedang mengantri untuk mendapatkan pelayanan agar tidak menunggu terlalu lama, sehingga waktu yang diperoleh mahasiswa tidak terbuang begitu saja

Penelitian yang dilakukan oleh (Noviyanto et al., 2014) yang berjudul "Sistem Informasi Kependudukan Desa Untuk Kemudahan Pelayanan Administrasi Desa Berbasis Web Mobile, Fiftin Noviyanto". Tujuan penelitian yang dilakukan adalah untuk memudahkan pegawai desa dan masyarakat agar pelayanan bisa dilakukan dengan cepat dan tepat sehingga akan mengurangi waktu pelayanan yang biasanya membutuhkan waktu yang cukup lama.

\section{METODE PENELITIAN \\ Teknik Pengumpulan Data}

Metode penelitian menjelaskan rancangan kegiatan, ruang lingkup atau objek, bahan dan alat utama, tempat, teknik pengumpulan data, dan teknik analisis penelitian.

Dalam melakukan penelitian senantiasa memerlukan suatu metode penelitian yang sesuai dengan pokok permasalahan yang di teliti. Metode penelitian pada dasamya merupakan cara ilmiah untuk mendapat data untuk tujuan tertentu (Sugiyono, 2016). Berdasarkan data tersebut, metode yang digunakan oleh peneliti dalam penelitian ini adalah metode grounded (grounded research). Metode grounded adalah suatu metode penelitian yang berdasarkan fakta dan menggunakan analisis pembanding dengan tujuan mengadakan generalisasi empiris, menetapkan konsep, membuktikan teori, mengembangkan teori, pengumpulan dan analisis data dan dalam waktu yang bersamaan dan dalam penelitian ini data merupakan sumber teori.

Tempat penelitian dilakukan pada Kantor Desa Cisaat yang bertempat di jalan Cipari Nomor 56 Desa Cisaat Kecamatan Cicurug Kabupaten Sukabumi.

Dalam mengumpulkan data, keterangan dan rancangan program yang dibutuhkan untuk Analisis Perancangan Sistem Administrasi Pelayanan Publik Studi Kasus Kantor Desa Cisaat Menggunakan Java Netbeans, peneliti menggunakan metode pengumpulan data sebagai berikut:

1. Metode Lapangan

Metode ini di lakukan peneliti secara langsung untuk mengumpulkan data dan keterangan yang diperlukan untuk Analisis Perancangan Sistem Administrasi Pelayanan Publik Studi Kasus Kantor Desa Cisaat Menggunakan Java Netbeans. Data-data tersebut dikumpulkan peneliti dengan cara sebagai berikut :

a. Wawancara

Wawancara merupakan proses memperoleh keterangan dengan cara mengajukan pertanyaanpertanyaan yang relevan dengan kebutuhan data yang dikumpulkan oleh peneliti kepada narasumber yang terkait dengan sistem yang akan diteliti. 
Peneliti melakukan wawancara langsung dengan Bapak Nanak Sukron, S.IP Selaku Kepala Desa Cisaat. Pada wawancara kali ini, secara umum peneliti menanyakan bagaimana sistem pelayanan administrasi publik di kantor Desa Cisaat berjalan. Kemudian Peneliti melakukan wawancara dengan Ibu Lisnawati, S.Pd selaku Kaur TU dan Umum di kantor tersebut untuk menanyakan perihal pengarsipan dan teknis pelaporan yang sedang berjalan.

b. Observasi

Peneliti mempelajari dan melakukan pengamatan secara langsung pada sistem pelayanan yang masih dilakukan secara manual dengan komputerisasi sederhana serta penyimpanan data yang juga masih manual. Pengamatan dilakukan pada 22 April 2019 hingga 29 April 2019. Dari pengamatan yang dilakukan oleh peneliti maka didapat beberapa masalah yang dihadapi oleh peneliti dan rekan.

2. Studi Pustaka

Studi kepustakaan adalah teknik pengumpulan data dengan mengadakan studi penelaahan terhadap buku-buku, literatur-literatur, catatan-catatan, dan laporan-laporan yang ada hubungannya dengan masalah yang dipecahkan.

Pengumpulan data dan informasi yang peneliti lakukan untuk merancang sistem pelayanan dengan cara:

a. Mempelajari buku-buku literatur tentang menganalisis dan mendesain sebuah sistem.

b. Mempelajari buku pemrograman JAVA untuk menginteraksikannya dengan MySQL.

Dalam langkah awal yang dilakukan dalam pengembangan sistem adalah dengan menentukan model sistem yang akan digunakan, Langkah-langkah yang dilakukan oleh peneliti dalam melakukan penelitiannya yakni dengan menggunakan sistem waterfall.

\section{Langkah-langkah Pengembangan Sistem}

Tahapan-tahapan dari paradigma waterfall dapat diuraikan sebagai berikut (Larasati \& Masripah, 2017) :

1. Persiapan Data, mengumpulkan data kebutuhan seluruh elemen sistem seperti data-data yang digunakan dimana elemen-elemen tersebut dapat menunjang dalam pelaksanaan proyek.

2. Analisis Data dan Proses, melakukan pengumpulan data dengan berfokus pada perangkat lunak, meliputi informasi, fungsi masing-masing bagian sistem, kerja atau cara kerja dan antar muka.

3. Perancangan, merancang struktur data, arsitektur perangkat lunak, rincian procedural dan karakteristik antar muka.

4. Pengkodean, tahapan untuk membuat suatu kode tentang aplikasi yang akan dibuat agar dapat dibaca dan diterjemahkan oleh komputer.

5. Pengujian

Memastikan semua fungsi sistem bekerja dengan baik dan menjamin kualitas aplikasi.

6. Implementasi dan Maintenance

Mengkoreksi dan memperbaiki kesalahan pada perangkat lunak yang baru diketahui pada saat perangkat lunak digunakan.

Basis data terdiri atas 2 kata, yaitu Basis dan Data. Basis kurang lebih dapat diartikan sebagai markas atau gudang, tempat bersarang/berkumpul. Sedangkan Data adalah representasi fakta dunia nyata yang mewakili suatu objek seperti manusia (pegawai, siswa, pembeli, pelanggan), barang, hewan, peristiwa, konsep, keadaan, dan sebagainya, yang direkam dalam bentuk angka, huruf, simbol, teks, gambar, bunyi, atau kombinasinya. (Fathansyah, 2015)

Pada aplikasi sistem ini digunakan basis data sebagai pelengkap program seperti data penduduk, data perangkat desa dan laporan register pelayanan. Basis data yang digunakan adalah MySql.

\section{HASIL DAN PEMBAHASAN}

Menurut Yakub menyatakan sistem adalah sekelompok elemen-elemen yang terintegrasi dengan tujuan yang sama untuk mencapai suatu tujuan.(Yakub, 2014), Sedangkan menurut Abdul Kadir Sistem merupakan sekumpulan elemen yang saling terkait atau terpadu yang dimaksudkan mencapai suatu tujuan.(Abdul Kadir, 2014) maka dari dua pendapat tersebut dapat disimpulkan sistem adalah kumpulan atau gabungan dari beberapa unit yang saling bekerja sama sesuai dengan 
fungsi dan porsinya masing-masing untuk mencapai suatu tujuan tertentu. Menurut Mohamad Subhan Perancangan adalah proses pengembangan spesifikasi baru berdasarkan rekomendasi hasil (Subhan, 2012), Suatu sistem memiliki karakteristik atau memiliki sifat-sifat yang tertentu, yaitu komponen, Batasan Sistem, Lingkungan Luar Sistem, Penghubung, Masukan(Input), Keluaran (Output), Pengolahan Sistem (Process), Sasaran dan Tujuan (Objective and Goal) (Ladjamudin AlBahra, 2013). Menurut Tata Sutabri kamus data dibuat berdasarkan arus data yang ada pada DFD. Arus data yang berada di DFD bersifat global dan hanya menunjukkan nama arus datanya saja, dengan menggunakan kamus data analisis sistem dapat mendefinisikan data yang mengalir dalam sistem dengan lengkap (Sutabri, 2012).

Menurut Hardiyansyah dalam konteks pemerintahan daerah, pelayanan publik dapat disimpulkan sebagai pemberian layanan atau melayani keperluan orang atau masyarakat dan atau organisasi lain yang mempunyai kepentingan pada organisasi itu, sesuai dengan aturan pokok dan tata cara yang ditentukan dan ditunjukan untuk memberikan kepuasan kepada penerima layanan, atau dengan kata lain pelayanan merupakan suatu proses bantuan kepada orang lain dengan cara-cara tertentu yang memerlukan kepekaan dan hubungan interpersonal agar terciptanya kepuasan dan keberhasilan.(Hardiyansyah, 2011) Menurut Sahya Anggara administrasi diartikan sebagai suatu proses pengorganisasian sumber-sumber sehingga tugas pekerjaan dalam organisasi tingkat apapun dapat dilaksanakan dengan baik(Sahya, 2012).

\section{Analisis Permasalahan}

Berdasarkan penelitian yang peneliti lakukan di Pemerintahan Desa Cisaat, peneliti dapat menganalisis permasalahan yang terjadi pada sistem administrasi pelayanan publik yang ada di Pemerintahan Desa Cisaat. Masalah-masalah tersebut adalah :

1. Ketika ada pemohon yang ingin memperbaiki berkas pengantar yang telah mereka buat, perangkat desa memerlukan waktu yang cukup lama untuk mencari data berkas tersebut.

2. Saat ingin membuat laporan perangkat desa harus memilih dan memilah kembali pelayanan yang telah dibuat.

3. Dalam penyimpanan data Pemerintahan Desa Cisaat tidak memiliki password khusus sehingga data bisa dibuka oleh semua orang dan bisa menimbulkan penyalahgunaan data.

\section{Alternatif Penyelesaian Masalah}

Dari masalah-masalah yang telah ditemukan peneliti dalam sistem administrasi pelayan publik di Kantor Pemerintah Desa Cisaat, maka peneliti berusaha memberikan beberapa alternatif penyelesaian masalahnya, yaitu:

1. Perancangan Sistem yang dapat mempermudah dan mempercepat pengolahan data seperti pencarian, menambah, mengubah dan menghapus sehingga membuat pelayanan lebih efektif.

2. Perancangan sistem yang mampu membuat laporan secara otomatis memisahkan antara jenis pelayanan sehingga perangkat desa tidak perlu melakukan pembuatan laporan secara manual yang memerlukan waktu cukup lama.

3. Pembuatan username dan password khusus yang hanya diketahui oleh kalangan tertentu sehingga data tidak bisa diakses oleh orang lain dan mengurangi resiko terjadinya penyalahgunaan data.

\section{Diagram Alir Data (DAD) Sistem yang Berjalan}

Sistem Administrasi pelayanan publik yang berjalan saat ini dapat digambarkan melalui Diagram Alir Data (DAD) sebagai berikut: 


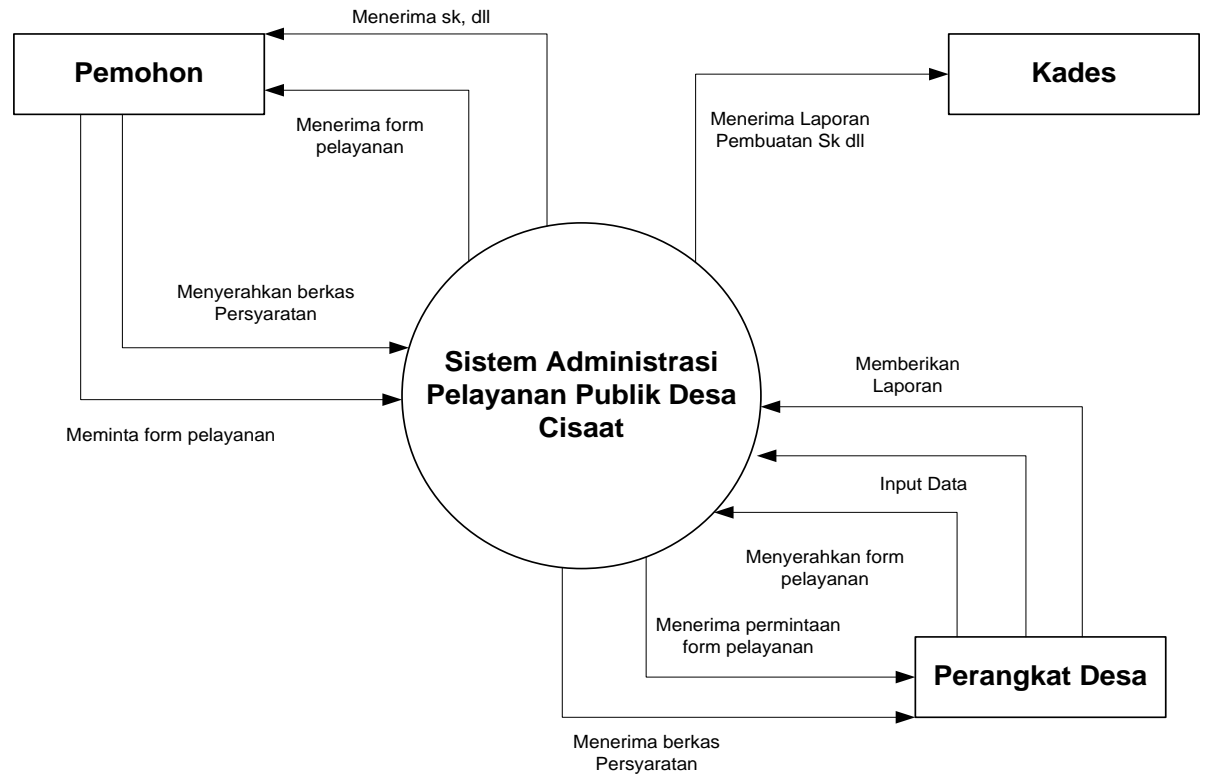

Gambar 1. Diagram Konteks Sistem Berjalan

Gambar diatas menunjukkan sistem pelayanan publik yang dilakukan pada Pemerintahan Desa Cisaat masih menggunakan komputerisasi sederhana (Microsoft Word) Adapun proses yang berlangsung pada pelayanan publik di Kantor Desa Cisaat adalah sebagai berikut:

1. Proses Pendaftaran, proses ini diawali dengan datangnya pemohon ke kantor Desa Cisaat untuk mengisi form pelayanan yang diberikan oleh perangkat desa. Dalam form permohonan tersebut pemohon memilih jenis pelayanan yang mereka butuhkan. Jenis pelayanan yang tersedia yaitu Pelayanan Kependudukan dan Pelayanan umum.

2. Pelayanan Kependudukan atau Pelayanan Umum, perangkat Desa menerima form pelayanan yang sudah diisi oleh pemohon. Pemohon wajib membawa persyaratan yang sudah ditentukan oleh pemerintah desa. Bila pemohon tidak membawa persyaratan yang sudah ditentukan maka permohonan form pelayanan tersebut tidak bisa diproses.

3. Proses Input Data, Perangkat Desa menulis data pemohon sesuai dengan kebutuhan yang diharapkan pemohon.

4. Laporan, Perangkat desa membuat laporan yang akan diserahkan kepada Kepala Desa.

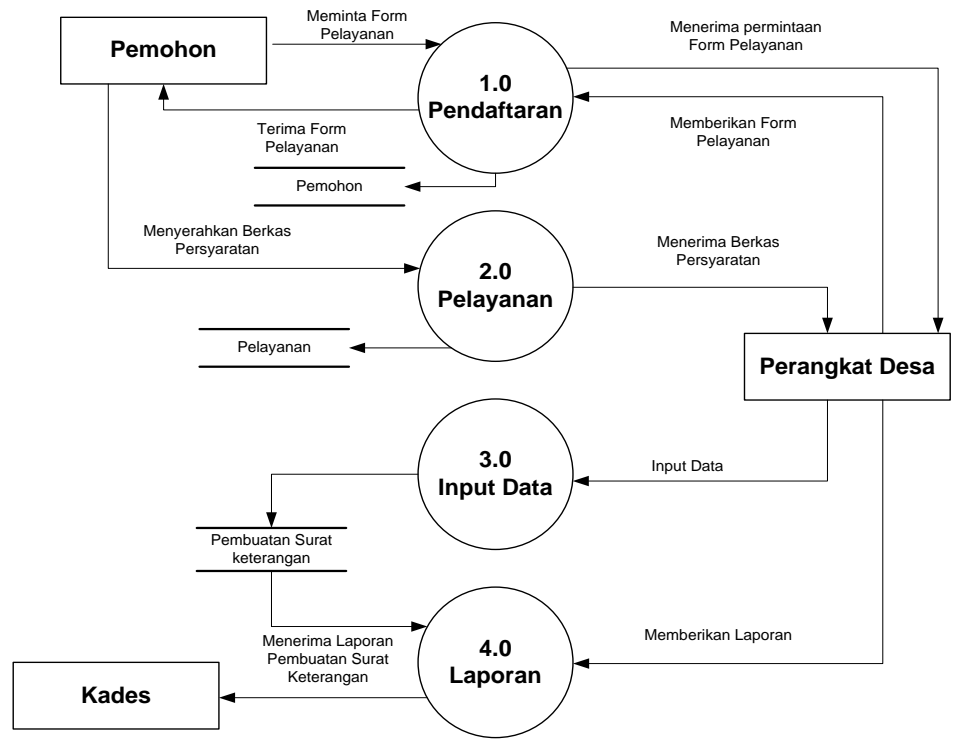

Gambar 2. Diagram Nol Sistem Berjalan

Gambar diatas menunjukkan rincian diagram konteks sistem berjalan dari pelayanan publik yang dilakukan pada Pemerintahan Desa Cisaat. Perangkat Desa menulis data pribadi pemohon kedalam 
buku register pelayanan kemudian Perangkat Desa membuatkan berkas pengantar pelayanan yang dimaksud pemohon melalui aplikasi Microsoft word.

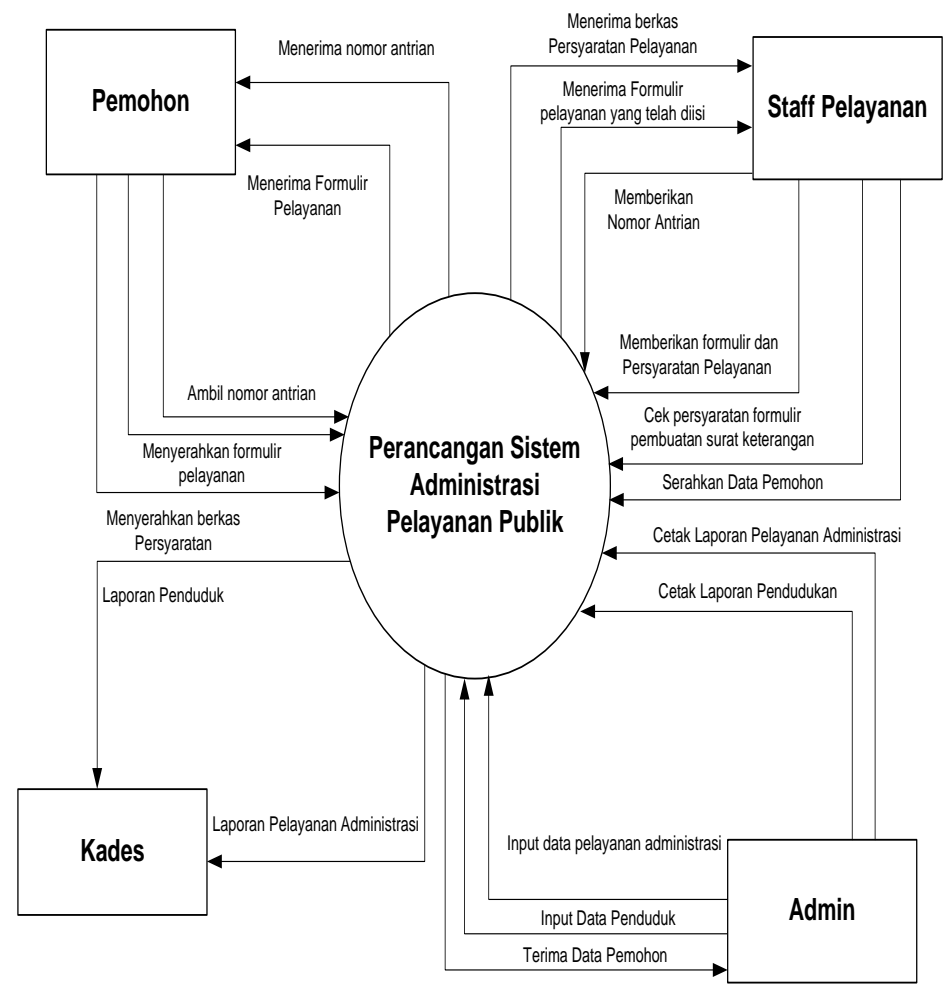

Gambar 3. Diagram Konteks Sistem Diusulkan

Gambar diatas menunjukkan diagram konteks Sistem yang diusulkan peneliti merupakan sistem yang dibuat khusus untuk mendata pelayanan pembuatan surat keterangan warga Desa Cisaat yang sebelumnya masih menggunakan sistem manual yang kurang efisien dan tidak efektif karena hanya dikerjakan dengan satu lembar kerja pada Microsoft Word sehingga menimbulkan kerancuan dalam pengerjaannya. Berikut ini adalah aturan bisnis sistem yang diusulkan oleh peneliti, diantaranya:

1. Proses Pendaftaran, meliputi Pemohon meminta nomor antrian yang kemudian pemohon mengisi form pelayanan.

2. Proses Pelayanan pembuatan surat keterangan, Staff pelayanan memanggil nomor antrian kemudian Pemohon menyerahkan form pelayanan dan persyaratan berkas yang diperlukan.

3. Proses penyerahan data Staff pelayanan memberikan data pemohon yang akan membuat surat keterangan kepada admin untuk di input.

4. Proses Input Data, admin menginput data pemohon sesuai dengan jenis pelayanan yang dimaksud pemohon dan disimpan kedalam database masing-masing jenis pelayanan.

5. Proses Pelayanan Selesai, admin menyimpan data para pemohon yang memperoleh pelayanan ke dalam database pelayanan.

6. Proses pembuatan laporan, Admin membuat laporan masing-masing jenis pelayanan yang akan diserahkan kepada Kepala Desa. 
JRAMI (Jurnal Riset dan Aplikasi Mahasiswa Informatika)

Vol QZ No $\mathrm{Cl}$ Tahun ZQZI

e-ISSN : $2715-8756$

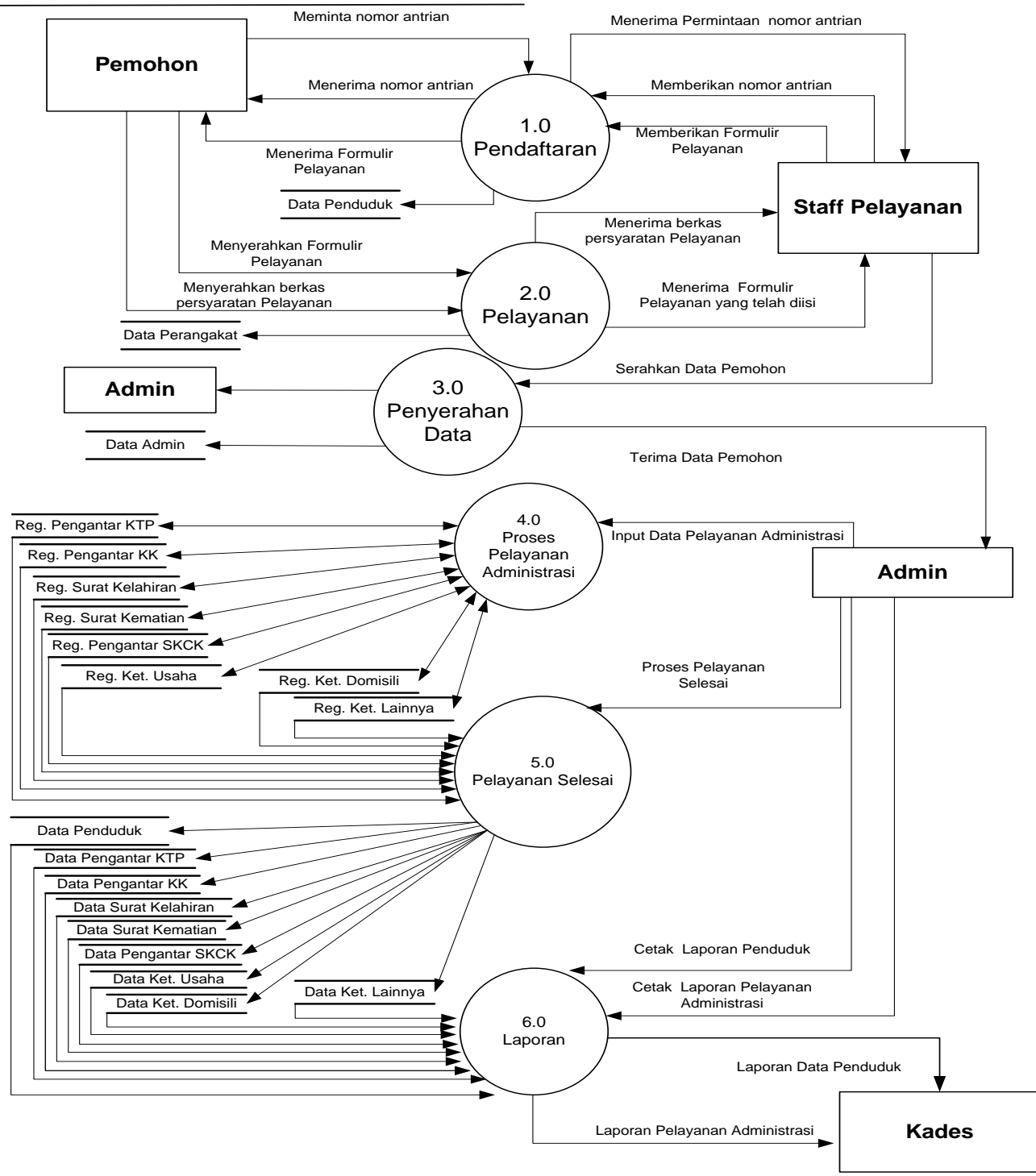

Gambar 4. Diagram Nol Sistem Yang Diusulkan

Gambar diatas menunjukkan diagram nol sistem yang diusulkan dari sistem administrasi pelayanan publik pada kantor Pemerintahan Desa Cisaat.

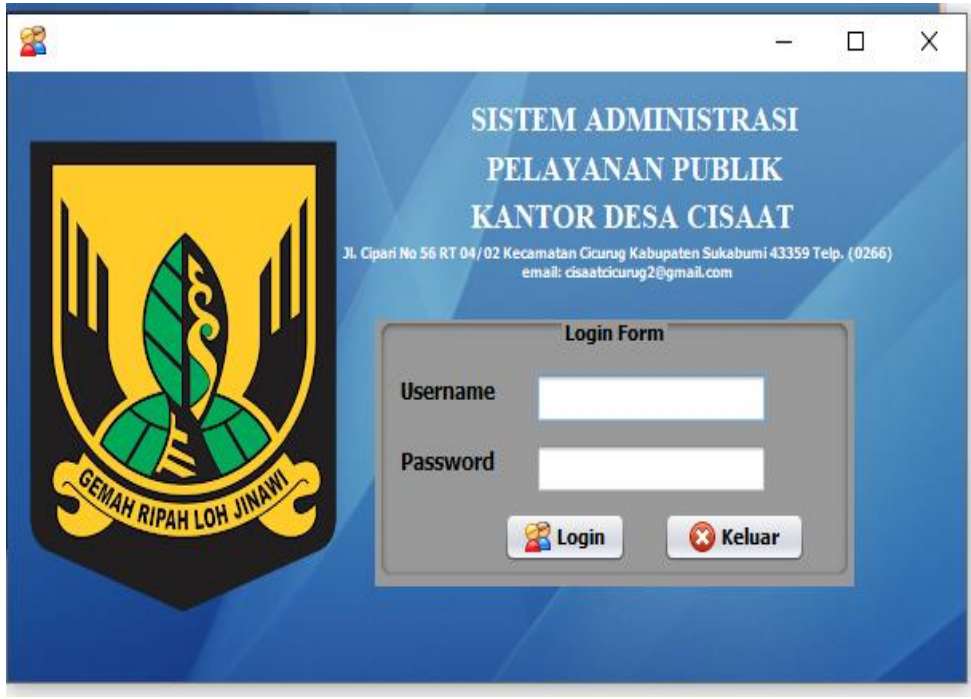

Gambar 5. Tampilan Layar Login 
Gambar 5 merupakan tampilan layar login, ini digunakan sebagai kata kunci sebelum admin masuk ke program utama agar tidak sembarangan orang dapat membuka aplikasi pelayanan publik sehingga akan mengurangi resiko terjadinya penyalahgunaan data.

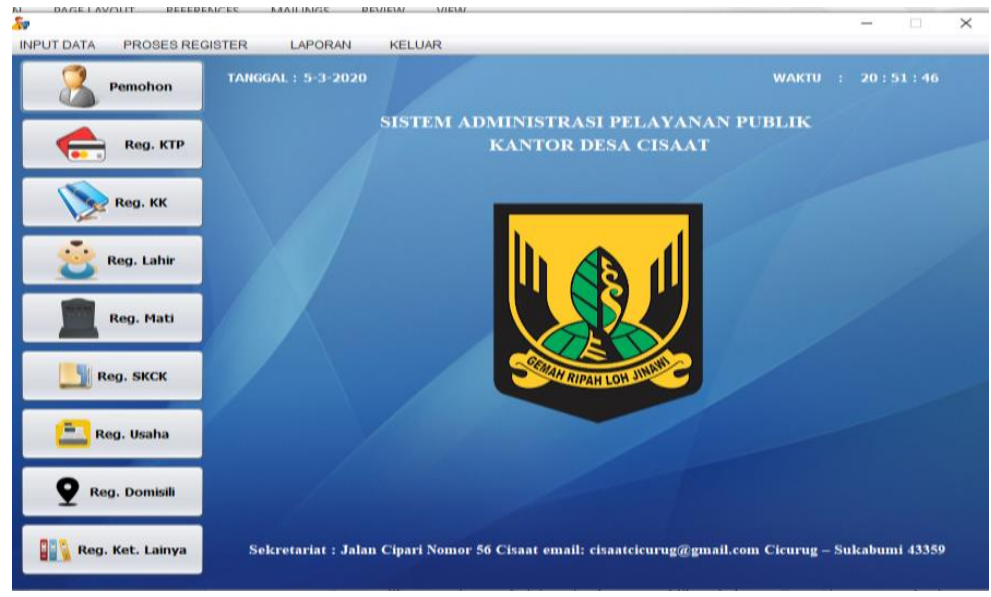

Gambar 6. Tampilan Menu Utama

Gambar 6 merupakan Tampilan menu utama dimana akan terbuka jika login telah berhasil dilakukan admin. Di menu utama ini terdapat tiga pilihan, yaitu input data proses register dan laporan.

\section{SIMPULAN}

Dengan dibuatnya sistem administrasi pelayanan publik pada kantor Desa Cisaat, semua kegiatan yang berhubungan dengan administrasi pelayanan warga masyarakat Desa Cisaat tidak dilakukan secara manual seperti sebelumnya. Dengan adanya pengoperasian secara komputerisasi, peneliti menarik simpulan yang dapat memberikan beberapa keuntungan sebagai berikut:

1. Dengan menggunakan aplikasi sistem administrasi pelayanan publik yang dibuat ini dapat memaksimalkan kinerja perangkat desa yang mengelola langsung data-data permohonan pelayanan warga masyarakat Desa Cisaat.

2. Memudahkan perangkat desa sebagai admin dalam pencarian data dan meng-update atau mengoreksi data-data bila terjadi kesalahan dalam penginputan.

3. Dengan adanya sistem baru ini bisa mempermudah perangkat desa dalam melakukan pengarsipan data secara efektif serta keamanan data lebih terjamin karena sistem menggunakan username dan password khusus sehingga meminimalisir terjadinya penyalahgunaan data.

4. Proses pembuatan laporan dapat dilakukan dengan cepat dan akurat serta efektif oleh perangkat desa.

\section{DAFTAR PUSTAKA}

Abdul Kadir. (2014). Pengenalan Sistem Informasi Edisi Revisi. In Edisi Revisi.

B, J. E., \& Angwarmasse, W. (2012). Model Antrian Fifo (First-in First-Out) Pada Pelayanan Mahasiswa Fakultas Teknik Universitas Janabadra Berbasis Multimedia. Jurnal Teknik.

Fathansyah. (2015). Basis Data. Revisi Kedua. In Informatika, Bandung. https://doi.org/10.1136/jnnp.2006.100248

Hardiyansyah. (2011). Kualitas Pelayanan Publik. Gava Media.

Ladjamudin Al-Bahra. (2013). Analisis Dan Desain Sistem Informasi. In Analisis Dan Desain Sistem Informasi.

Larasati, H., \& Masripah, S. (2017). Analisa Dan Perancangan Sistem Informasi Pembelian Grc Dengan Metode Waterfall. None.

Noviyanto, F., Setiyadi, T., \& Wahyuningsih, I. (2014). JURNAL INFORMATIKA Vol. 8, No. 1, Januari 2014. Implementasi Sikades (Sistem Informasi Kependudukan Desa) Untuk Kemudahan Layanan Administrasi Desa Berbasis Web Mobile. https://doi.org/10.26555/JIFO.V8I1.A2084

Sahya, A. (2012). Ilmu Administrasi Negara. CV. Pustaka Setia.

Subhan, M. (2012). Analisa PErancangan Sistem. In Analisa perancangan sistem.

Sugiyono, P. D. (2016). metode penelitian kuantitatif, kualitatif,dan R\&D. In Alfabeta, $c v$.

Sutabri, T. (2012). Analisis Sistem Informasi. In Analisa Sistem Informasi.

Yakub. (2014). Pengantar Sistem Informasi. Igarss 2014. https://doi.org/10.1007/s13398-014-0173-7.2 